University of South Florida

DIGITAL COMMONS

Digital Commons @ University of

@ UNIVERSITY OF SOUTH FLORIDA

South Florida

Government and International Affairs Faculty

Publications

Government and International Affairs

$10-2011$

\title{
Communications Networks, Movements and the Neoliberal City: The Media Mobilizing Project in Philadelphia
}

\author{
Dan Berger \\ University of Pennsylvania, dberger@asc.upenn.edu \\ Peter N. Funke \\ University of South Florida, pnfunke@usf.edu \\ Todd Wolfson \\ Rutgers University, twolfson@cri.rutgers.edu
}

Follow this and additional works at: https://digitalcommons.usf.edu/gia_facpub

Part of the International Relations Commons

\section{Scholar Commons Citation}

Berger, Dan; Funke, Peter N.; and Wolfson, Todd, "Communications Networks, Movements and the Neoliberal City: The Media Mobilizing Project in Philadelphia" (2011). Government and International Affairs Faculty Publications. 118.

https://digitalcommons.usf.edu/gia_facpub/118

This Article is brought to you for free and open access by the Government and International Affairs at Digital Commons @ University of South Florida. It has been accepted for inclusion in Government and International Affairs Faculty Publications by an authorized administrator of Digital Commons @ University of South Florida. For more information, please contact digitalcommons@usf.edu. 


\title{
Communications Networks, Movements and the Neoliberal City: The Media Mobilizing Project in Philadelphia
}

\author{
Dan Berger \\ University of Pennsylvania \\ Annenberg School of Communicaotn \\ 3620 Walnut Street \\ Philadelphia PA 19104 \\ Peter Nikolaus Funke \\ Department of Government and International Affairs, University of South Florida \\ pnfunke@usf.edu \\ http://gia.usf.edu/faculty/pfunke/ \\ $1-(215)$ 385-6151 \\ Department of Government and International Affairs, University of South Florida \\ 4202 East Fowler Avenue, CIS 1040 \\ Tampa, FL 33620-9951 \\ USA
}

\section{Todd Wolfson}

Department of Journalism and Media Studies, Rutgers University

twolfson@rci.rutgers.edu

School of Communication and Information, Rutgers University

4 Huntington St

New Brunswick, NJ 08901

USA 
On a Sunday in late March 2008, seventeen budding videographers came to their third day-long class held by the Media Mobilizing Project (MMP) and Juntos, an immigrant justice organization, to learn basic video and web skills. The workshop series, entitled Our City Our Voices, catered to Philadelphia's growing population of immigrants and low-wage workers with students coming from local service sector unions SEIU and UNITE HERE, the Taxi Workers Alliance, and Philadelphia’s diverse immigrant communities. Ranging in age from 20 to 60 years old, the students came, as Beso Amore, an Eritrean immigrant and taxi driver, explained, "to learn how to use video and the internet to tell our stories and build our fight.”

The workshop took place at the Songhai City Cultural Center, in a part of North Philadelphia known as Brewerytown. Emblematic of the changing nature of Philadelphia's economic, political and social landscape, Brewerytown got its name from the history of breweries which once operated in this part of the city and provided both work for the neighborhood and German inspired-Lager to the city and country. Like many of Philadelphia's once proud industries, over the course of the $20^{\text {th }}$ century the breweries left the city or shut down, and with the loss of the economic base, the neighborhood slowly transformed into an area of densely concentrated poverty. In recent years, Brewerytown reemerged as the sight of an intense battle over urban development when the city government targeted Songhai City for seizure through eminent domain in order to turn it over to a developer that was building luxury condominiums in the neighborhood. After months in court, Songhai City was returned to the original owner, Jimmy Howard, but not before Brewerytown became ground zero for struggles over gentrification and urban development in Philadelphia. 
On the first day of the workshop, Howard introduced students to the space, explaining that Songhai City was a place for community to come and learn together in the face of overpowering odds. The class, an eight-week-long effort to offer both the skills and hardware for students to, as the course goals put it, "amplify their voices" in the "digital age," was a mixture of political education and simple videography and web skills. On this particular Sunday, students watched and dissected different documentary style videos. Subsequently, they broke up into production teams and went out into the neighborhood to film shorts about gentrification, immigration and community participation. After a few hours the students came back and looked at the footage they had captured and discussed the type of videos they would begin to produce collectively in the coming weeks.

At the end of the six-hour class, a team of high school students from the Philadelphia Student Union came to the Songhai City armed with audio and video equipment. Several months earlier, the students were in a similar MMP audio/video workshop where they learned audio journalism skills. The class led to the development of "On Blast," a youth-run radio show representing "the needs and interests of young people," and broadcasting on a West Philadelphiabased low-power FM radio station, WPEB. The students came to Songhai City to interview taxi workers about an impending strike over the proposal to place Global Positioning System (GPS) machines in the city's cabs. The students took turns asking taxi drivers questions about their working conditions and their organizing.

The interviews were done as part of a news story for "On Blast.” The moment also offered critical communication between high schools students, in Philadelphia's failing public schools, fighting for educational equity across the region and cab drivers fighting for a living 
wage and the right to a voice in their workplace. As one of the students, Rorng Chea, explained, “this was a moment where we learned that our struggle over equitable education is connected to the struggle of drivers.” The students produced two different audio segments from the interview. One segment was used as a news piece in the next broadcast of their radio show. The second piece was a short public service announcement the students made with the cab drivers so they could use it on the internet and other venues to get support for the approaching strike.

That Sunday at Songhai City opens a window onto the many ways that communication can play a connective role for social justice groups in the contemporary city. During the workshop, low-wage workers and immigrants came together to watch documentaries, learn video skills and work together to collectively create and share stories about Philadelphia. Later in the day, taxi workers and teenagers shared stories of struggle and collaborated on media production to educate the public and facilitate bonds among grassroots groups. These connections, between taxi workers and students from public high schools, between local filmmakers and recent immigrants, are the precise exchanges motivating the Media Mobilizing Project in its efforts to use media as a bridge conjoining poor people's movements from across the fragmented urban landscape in an effort to build a shared movement to end poverty led by the poor themselves.

\section{RETHINKING NETWORKS}

This article examines the work of the Media Mobilizing Project in order to better understand localized, communications-based networks as an organizational response to the fragmenting nature of the neoliberal city (Caldeira 2000, Sites 2007, Smith 1996). While the fragmentation of communities and isolation of the poor can be found across a range of 
deindustrialized cities in the United States and globally, the effect of deindustrialization and neoliberalism is asymmetrical, making each city an important site to study both the social conditions as well as the political responses. In this article, we argue that networked organizational structures are a response to the isolated nature of disenfranchised communities in the urban United States. Moreover, our focus on the local level and everyday practice of networked social movement renders a more nuanced picture of the use of network forms of organizing and of the use of media and communication technologies, both old and new, that complicate contemporary scholarship.

Most analyses of networked social movements have focused on national and transnational phenomena. Such studies have emphasized both the democratizing potential of new media, specifically the internet, as well as the role of the internet in interlinking transnational phenomena (Juris, 2008; Kidd, 2003; della Porta, et al., 2006; Khasnabish, 2008; Day 2005; McCaughy \& Ayers, 2003). Through examinations of protest tactics and alternative media practices, scholars have demonstrated the ways technology can circumvent national borders (Keck \& Sikkink 1998). They have also demonstrated communication technologies as a robust terrain in diverse mechanisms of globalization-including both the diffusion and disruption of dissent (Arquilla \& Ronfeldt, 2001; Dyer-Witherford, 1999; Aneesh, 2006). Yet these and similar studies have not examined seriously enough how such networks operate at the local and everyday level. The global and transnational focus tends to lose sight of the fact that networks, as with other political expressions, are lived and experienced locally. Studies of networks that operate at the national and transnational scale, are inclined to sidestep the continuous challenges, such as the digital divide, that network structures face in their everyday enactments, practices 
and operations, which are intrinsically related to their particular local setting. Reinserting the local into discussions of networked politics troubles the easy distinction between vertical and horizontal organizational structures (Escobar, 2008). Locally networked social movements show more hybridized form, intertwining vertical and horizontal dimension.

Using MMP as a case study, we examine the role communication plays in developing a local network. We question the reified status of new media in the development of networked movements, particularly when working with poor and working class communities that have minimal access to contemporary technologies. We argue that diverse forms of media, both old and new, are crucial sites where and how such networks form, are sustained and developed. A multiplatform media and communications infrastructure that includes “older” on- and offline media tools such as radio or face-to-face interactions are often more important to the sustenance of a local network than new media technologies specifically. Such an infrastructure, which is multimedia and not merely internet dependent, provides the crucial apparatus to utilize the ubiquity of various media tools, whether new or old. Furthermore, as this article shows, how and what kind of media is used to coalesce groups and movements in the neoliberal city depends on the particular context at hand. Older forms such as the radio are better geared towards interlinking, for instance, cab drivers while video and internet based forms are well situated to generate linkages across the diversity of the constitutive MMP groups such as hotel workers, cab drives, students, or health care workers. Moreover, we argue that media and communication needs to be complicated as tools for developing linkages and networks. Creating contemporary linkages and networks is not merely based on "online” forms of media such as radio or the 
internet but as much on face-to-face interactions. It is precisely the nexus of "on- and offline" communications where networked movement building is taking place.

In this article, we examine MMP's use of media and communication to analyze how its challenges and its conceptions contribute to scholarly notions of networked social movements. Studying local networks such as MMP reveals a great deal about the role of communication as a strategy for social movement building in response to globalizing capitalism. While there is growing research on national and transnational networked social movement challenges to capitalist globalization, some of the most interesting lessons come from local urban networks. Shifting the spatial focus in this way directs our attention to networks as strategic combinations of context-specific work that bridges online and offline spaces.

After describing our methods, we proceed by describing the roots of MMP in relation to the neoliberalization of the city. We then look more in depth at two of its branches: the video classes referenced above and its involvement in helping build an alternative media infrastructure through a low-power FM radio station. We conclude by examining the fruits and challenges of this merger of media and social movements.

\section{METHOD}

This paper provides a brief overview of the Media Mobilizing Project in relation to and dialogue with theories of social movement networks, examples of media activism, and realities of global capitalism. We see this paper as an ethnographic experiment of new media and urban social movements. It is a modest step toward answering Cottle’s (2000) call for news ethnographies that speak to the contemporary media landscape in its myriad forms. Undertaken 
by three researchers, the fieldwork consists of a mixture of participant observation across the different components of the Media Mobilizing Project's work, as well as twenty interviews from across the broad membership of MMP. Interview subjects included MMP cofounders, filmmakers working with the organization, and activists from its various partner groups. They ranged from teenagers to senior citizens, and about half were immigrants from Latin America, Southeast Asia, or Africa. Of those born in the United States, the majority were people of color. These dynamics reflect the demographics of not just MMP's work, but of Philadelphia’s working class communities. Interview comments are integrated throughout the text—and, unless otherwise noted, quotations can be assumed to be from interviews. As is typical of ethnographic research, the names of interview subjects have been changed.

The research took place intermittently from the relative beginning of MMP in the spring of 2006 until the spring of 2010. As a collaborative project, the three researchers come from three different fields—anthropology, communications, and political science—and our collective analysis is shaped by our respective disciplinary trainings. The research is also the product of combining traditional ethnographic practices with engaged research (Sanday, 1976, 1990; Hale 2008) While two of the authors approach the topic as academic researchers interested in the intersection between contemporary social movements and communications, the third is one of the founders of the organization as well as a researcher. He undertook his doctoral research on Indymedia, a forerunner of MMP, and much of his research led to the development of MMP. This author's insider status and deep engagement with MMP is balanced by the other authors' interest and experience in the field broadly. 


\section{ROOTS}

Despite its media production, MMP's roots are less in media making than in the social networks of antipoverty organizing in Philadelphia. In the 1990s two of MMP's co-founders, Josh Poster and Sheetel Gupta, worked with Empty the Shelters, Union of the Homeless, the Kensington Welfare Rights Union (KWRU) and the University of the Poor, all groups that fought for expanded media attention in their campaigns to organize homeless people and impoverished communities. During this period, organizers focused on the intersection between poverty and media. As one member of these different groups, David Erich, explained, "the local newspapers stopped covering KWRU, and in that moment we realized we had to develop an alternative media strategy.” During this period, organizers connected to anti-poverty organizing in Philadelphia worked with several local media democracy activists and economic justice groups to organize a series of conferences called “Break The Media Blackout.” These conferences, held in Philadelphia 1997 and 2002 and modeled after a similar gathering in the Midwest in the early 1990s, focused both on the absence of issues of poverty in the mainstream media as well as alternative strategies for telling and sharing stories from the internet to public access TV. The conferences helped to coalesce media reform organizing in Philadelphia as organically part of economic justice organizing. While Philadelphia was a central node in this work, similar developments were occurring across the world. In the United States, various antipoverty groups_ _ often urban, frequently immigrant based, and self-consciously multiracial— increasingly embraced media as tools for organizing (e.g., Caruso, 2000; CIW, 2004). 
Combined with article co-author Stevens’ research on Indymedia and the Zapatistas, Poster and Gupta’s experience with the Break the Media Blackout conferences provided the foundation for MMP. A national week of action against Wal-Mart in 2005 provided the first opportunity for these activists to join media production and antipoverty organizing. Gupta helped plan the Philadelphia actions against Wal-Mart while working for Jobs with Justice. Stevens, then a graduate student at a local university, had been working with the Philadelphia Independent Media Center, and coordinated Indymedia's involvement in the week of action. The campaign coincided with the release of Robert Greenwald's documentary Wal-Mart: The High Cost of Low Price, and media factored prominently in the campaign. "The whole campaign was fought more in terms of air war than ground war,” Gupta says. IMC journalists interviewed workers, which were turned into audio pieces union stewards could use in their organizing, and Gupta involved local filmmakers in producing several short, anti-Wal-Mart commercials. The Ruckus Society, an organization which helps groups plan and use creative nonviolent direct action (Sellers, 2004), figured out a way to broadcast messages across buildings in the city. All these activities complemented more traditional forms of protest, such as pickets, against the corporate giant.

This combination of grassroots media production and labor organizing gave MMP its early raison d'être. “These battles are not just about management; they're about PR,” Gupta says. MMP formed to provide impoverished and disenfranchised communities with their own media as a way of both furthering the ends of each particular struggle and using media and communications to connect urban social justice organizations into a shared network. The strategic approach for the Wal-Mart campaign was thus not merely the documenting and making of media on behalf of those silenced by the mainstream media, but more importantly, connecting 
differently situated groups fighting Wal-Mart, from environmental activists and small business owners, to labor and concerned citizens, through media. The Wal-Mart campaign contained the seeds and helped define the trajectory of what would become MMP's strategic use of media to interlink and mobilize otherwise fragmented organizations and sectors, creating cross-issue networks and synergies.

The attempt to use media and communications to connect multiple sites of struggle came out of experiences of organizing in the contemporary fragmented city. Scholars have begun to examine how, in the wake of a globalizing economy, the structural and social conditions of contemporary U.S. cities have led to a mixture of service-sector, casualized working conditions (Harvey, 2005; Brenner and Theodore, 2002), fragmented and segregated neighborhoods (Smith, 1996; Massey and Denton, 1998), and a growing number of people living in deep poverty that are both isolated and disengaged from the political process (Goode and Maskovsky, 2001). This set of conditions frames life in the contemporary city and has led to isolated working conditions and disjointed communities. (Harvey, 2005; Dyer-Witheford, 1999). In response, local urbanbased social movements have experimented with organizational forms and strategies to change their contemporary environment.

Following the 2005 Wal-Mart campaign and week of action, a group of six Philadelphiabased organizers began to meet to discuss the development of an ongoing project based on the insights of that campaign. Through that process they began building relationships and producing media with Philadelphia-based organizations focused on labor, housing and anti-gentrification, immigrant justice, and youth and education. By early 2006, MMP was officially launched. Three years later, the MMP network consisted of ten groups focused on issues of labor, housing and 
education. The groups that originally made up the network were consciously asked to join and thus become constitutive parts of the broader MMP network due to their poor and working class constituencies, as well as their long-term goal of ending poverty through movement building. The six founders began fundraising and developing the institutional structures for an organization that could, as they saw it, use media to create a meta-organization of poor and working class groups and organizations. MMP's formation and its goals owe to the merger of poor people’s movements, with their focus on building human rights for economically disenfranchised communities, united across race (e.g., Jackson, 2007; Fox Piven \& Cloward, 1979) and the networked re-appropriation of new media as exemplified first by the Zapatistas in Mexico (Cleaver, 1996; Holloway and Peleaz, 1998; Ronfeldt and Arquilla, 1998) and then the global Indymedia movement (Halleck 2002; Kidd 2003; Morris 2004; Juris 2005.)

As such, MMP exemplifies two often-hailed cornerstones of contemporary movements: prefigurative network structures and the use of new media. For instance, Juris (2008) and Della Porta et. al. (2006) have argued that networks have not only given rise to the alter-globalization/ global justice movement but have demonstrated—prefigured—its political vision of transnational solidarity. Hardt and Negri (2004) have predicted that such fusions, pioneered by but not limited to the Zapatista rebels in Southern Mexico, hold out hope for a more democratic future by making organizations more participatory in the immediate while limiting the gap between means and ends. These and similar works have also emphasized the possibilities afforded by new media technologies, including most centrally the internet but also the cheap availability of cameras and other forms of mass communication. Put simply, communications technologies are the legs on which the contemporary networks of globalization walk. Electronic communication supplements 
or even supplants physical forms of connection within networks. Gupta summed this up by saying, "as society becomes more and more fragmented, then technology becomes more and more relevant in terms of how people can stay connected.”

Nevertheless, new information and communication technologies and correspondent horizontal or flat network structures have not solved the problems of conjoining differently situated sites of struggle, nor do they take the place of local face-to-face organizing. Bringing people together in face-to-face encounters are central for building community, for providing a space to share more intimately the increasingly fragmented experiences under neoliberalism of, for instance cab drives, students or hotel maids as well as for providing the necessary knowledge and technical know-how to overcome the digital divide. Flat network structures are also no panacea. Flat networks can uphold diversity but have more trouble generating and sustaining new communities, collectivities and organizations. These bodies require processes and apparatuses of linkage that can synthesize differences without forgoing diversity. This need is particularly evident when examining localized groups and networks such as MMP that engage in sustained organizing and institution building in urban settings. The scholarly literature, as well as some activists, have at times fetishized the movement-building capacity of new media technologies and purely horizontal network structures. Challenging this quixotic position, Nugent for instance, argues that many (northern) accounts of Zapatista's use of new media "suggests that their most distinctive feature as a political movement is to have shifted the object of struggle from control of the means of production to control of the means of communication; revolutionary ideals are to be advanced by the free exchange of rebel-friendly software and communications packages. But this way of thinking about the rebellion tends to block out the 
years of organizing that preceded January 1, 1994” and have been ongoing since (Nugent 1997: 166).

Controlling the means of communication is an important task in today's media-saturated society, and Nugent arguably does not give enough credit to the pivotal role new media plays in connecting the increasingly transient poor and working class constituencies. Janitors or taxi drivers, for instance, are increasingly diffused and atomized, no longer working at the same “assembly line.” The lack of shared work-spaces makes sustained organizing more challenging and reliant on the re-appropriation of the new communication technologies for their struggles. At the same time, however, Nugent reminds us about the irreducible need to study grassroots and placed-base organizing and institution building for which computers and the web, as well as the skills to operate them, are only some among several central pillars.

MMP's experience around its housing campaign exemplifies this point, stressing the persistence of on-the-ground movement building. Initially, MMP put substantial energy into the anti-gentrification efforts of its members groups concerned with housing. MMP used new media technologies as connective tissue, sharing stories, producing video and audio coverage and interconnecting groups and people. This occurred through media-based campaigns to both stop casinos from coming into Philadelphia and reevaluate property taxes. However, MMP’s housing work has not moved forward as dynamically as their work on new labor or education. The housing organizations that were a part of the MMP network lacked the financial resources, consistent constituency, and leadership density to proceed apace the other network organizations. The use of new media technology was not enough to overcome the obstacles of low organizational capacity, which has to be located in the weakness of the respective "off-line" 
dimensions. This housing example indicates the analytic prerogative to research contemporary social movements at the intersection of new media, network structures and the particular local contexts of everyday practices and enactments. The ensuing image, we hold, complicates our knowledge of contemporary social movements in general and the role of media, networks and local context in particular.

Still, the new communication technologies were vital for the birth of MMP and the growth of several of its network organizations. Of all the new media innovations, perhaps the most important one for understanding the genesis of MMP is the global network of Independent Media Centers, Indymedia. The Indymedia network, with its open access publishing that allows anyone to post to the site, has become a hallmark of the mass demonstrations associated with global justice organizing. Building on the relationship that the Zapatistas cultivated with global civil society, and their strategy of using communications to connect across struggles (Wolfson, 2009; Cleaver, 1998, Nogueria, 2002; Beckerman, 2003; Kidd, 2003), Indymedia enlisted a motley crew of activists into being journalists (Halleck, 2002; Nogueira, 2002: 293). Its on-theground footage outpaced that of more traditional media outlets, such as CNN, leading the Indymedia site to become a more utilized news outlet during the course of several mass demonstrations from Seattle to Genoa and beyond (Juris, 2005; Gillmor, 2004: 145; Platon \& Deuze, 2003; Setchell, 2002).

The IMC success in Seattle proved an inspiration, as chapters began to sprout up around the world—often in conjunction with mass protests. From the winter of 2000 to the fall of 2003, Indymedia grew at a pace of about one new site every eleven days. One of the aims of Indymedia activists was to create a transnational communications network that connected struggles across 
space and theme. This vision of the role of communications in building larger networks of struggle came from Indymedia's material and ideological connection to the Zapatistas, providing a crucial conceptual foundation for MMPs locally based network. More materially, Philadelphia Indymedia provided the initial home for MMP. The IMC served as MMP's fiscal sponsor in its first two years, and MMP learned from the network possibilities pioneered by the IMC. MMP activists still write for the local Indymedia website, and several MMP cofounders concede that they hope their approach of being rooted in poor people's movements will be taken up by others in the IMC network.

MMP is rooted in IMC-inspired media making, distributing material through its networks and using media to solidify its network. While the emphasis on networks, particularly offline networks, is perhaps the biggest challenge to the IMC model, the connection to the IMC is, however, only one half of the equation explaining the emergence of MMP. The other half is poor people's movements, and MMP's central focus on organizing around economic stratification. This emphasis presents further challenges to the IMC model, which has thus far eschewed any unified political analysis or embedded relationship to certain organizations, favoring instead a general open-access, anti-corporate approach. In that sense, MMP can be considered IMC 2.0more interactive, more multimedia, and more networked. MMP has placed greater emphasis than Indymedia on distribution mechanisms (Opel and Templin, 2005), using diverse forms of media and face-to-face organizing to connect poor people’s movements.

MMP's work is thus a collaborative initiative with one or more organizations in the Philadelphia area. MMP has for instance, organized media production classes that help train members of the different groups in media skills. In addition to the ten network organizations, 
MMP is affiliated with multiple partner organizations locally and nationally that are engaged in similar work around antipoverty organizing, labor and immigrant justice, and media democracy. Its “community board,” which helps determine the organization's priorities and plans, is a twenty-member body drawn from the ranks of member and partner groups. There are fifteen core members of MMP that coordinate these committees and MMP's public events. There are another 250 people that are in some way affiliated with the group, about a third of which would identify with doing work as MMP. Determining an exact number of participants is difficult, however, because MMP is at once an organization, with clear boundaries of membership, and a fluid network, in which many people can plug in (or drop out) based on the needs of a given moment or project. This porous structure, in many ways typical of network-based models (Juris 2008, Escobar 2008), lends MMP an often inchoate quality as well as a transitory nature which leads to dynamism but at times lack of consistency. This balance of structured organization and open network is part of MMP's strategy and part of its experiment. MMP works across organizations, displaying many of the horizontal qualities scholars have demonstrated of networks (de Landa, 2006; Escobar, 2009). Yet MMP and its network organizations each utilize structures and methods of decision making that are not purely horizontal. There are, in fact, identifiable leaders within MMP and its partner organizations, who are responsible for shaping the strategic directions of the network. As such, MMP's structure contains and combines both horizontal and vertical elements.

In the following section, we examine two of MMP's branches, both of which illustrate the relationship between media, networks and contemporary social movement based organizing in an urban setting: its Labor Justice Radio and the video trainings MMP coordinates. Both show 
the interactive, multimedia, and hybrid network form that contemporary urban social movement based organizing is taking in the neoliberal city.

\section{BRANCHES}

"[T]his is the most radical experience I have ever been part of."

- Perchik Silver MMP point person of Our City Our Voices

In June 2009, MMP opened an office in West Philadelphia with two network groups, the United Taxi Workers Alliance and the Philadelphia Student Union. MMP now has two spaces in which it produces audio and video materials. These sites are housed in the MMP office, and the office of low-power FM radio station WPEB. Most decisions over media content, however, are made in meetings held in community centers and private homes across Philadelphia. The group's media equipment is shared, distributed to people within the network when they need to cover a particular event or work on a given story. Editing and production are often done at home on laptop computers by one of the skilled media makers working with the group.

Two prominent examples of MMP’s work that illustrate the relationship between media, networks and contemporary social movement based organizing in an urban setting are its ongoing Labor Justice Radio and the video trainings MMP coordinates. Both projects show the context specific nature of how networks such as MMP engage in their particular local setting as well as the media strategy employed to connect otherwise atomized groups of poor and working class people in a neoliberalizing city that has resulted everywhere in greater disparity of wealth and precarity of labor, alongside a growing finance and information economy. Both initiatives 
show the crucial role that media play in sewing together groups and movements that face distinct but ultimately similar struggles against the neoliberalization of the city.

Labor Justice Radio:

Labor Justice Radio (LJR) airs on West Philadelphia’s community radio station WPEB 88.1FM. It has aired since September 5, 2008, as a monthly one-hour long radio program that claims to "advocate justice for all working people" (http://www.podomatic.com/profile/laborjusticeradio). It is the first radio show in the city that is "collaboratively produced by workers and labor leaders from across the taxi, service and commercial industries” (http://www.phillyimc.org/en/node/73672). The one-hour shows take on issues related to the various groups that are members of MMP. There are typically three to four stories of four- to ten-minute length per show as well as short news stories and music segments. The segments are produced by members of MMP's associated groups that have gone through an MMP-coordinated radio training. Two or three hosts introduce the program. The first show, for instance, included segments on UNITE HERE's boycott of Embassy Suites, recent immigration raids that targeted members of SEIU 32BJ, and two pieces on taxi workers: one about the creation of the Unified Taxis Workers Alliance of PA, and the other about efforts to win workers' compensation for injured taxi drivers.

MMP organizers started LJR as a way to consolidate it's network of worker organizations through a new West Philadelphia based community radio station, WPEB. (WPEB is an allvolunteer low-power radio station, which was originally operated by three media activist groups in Philadelphia: the Scribe Video Center, the Prometheus Radio Project, and the Philadelphia Independent Media Center/Media Mobilizing Project. Scribe Video Center acquired license to 
the station in 2006, and it began broadcasting in May 2008.) While LJR was from the start conceived of as using the medium of radio to organize and forge closer ties between the various constitutive groups of MMP, the emphasis on labor and radio grew out of the particular local conditions. The emerging focus on labor was partially due to pragmatic reasons: the labor groups involved with MMP were the strongest of the participating organizations. Moreover, there was a particular focus on taxi workers, because many cab drivers do not have internet access, but are in their cabs all day and consequently the radio seemed an important organizing tool for cab drivers. In that sense, MMP and taxi workers saw radio as a strategic organizing tool for this stratum of Philadelphia's service sector economy.

Sarah McKay is leading the radio trainings and is the core MMP coordinator of all MMP radio programs. She moved to Philadelphia in 2007 from Michigan, where she had done independent media work, including editing an independent grassroots newspaper and was part of a collective that put together weekly independent radio shows. She is one of a handful of experienced media makers that help lead MMP classes in media literacy and media production. Despite the stated labor emphasis, MMP's radio trainings focus as much on developing connections among grassroots groups as on labor. In the trainings, McKay pushed MMP's vision and strategy to use radio to generate solidarity and thicker connections between the various groups and struggles. The initial training started out with honing critical analytic skills using the coverage by mainstream media. McKay brought in news clippings as well as actual TV news clips about the groups that were present at the training. For instance, when the taxi drivers launched a strike, the learners would discuss the coverage that they received in the mainstream media. The group talked about what shaped the coverage, such as the ties to corporate advertisers 
or to parent companies and the underlying ideologies of the mainstream media. Using Herman and Chomsky’s notion of filters (Herman and Chomsky, 1988), McKay explained: "So what are our filters? We want to break down ideas that there is this neutral that we are going to be neutral. We are claiming our position as saying that organizing is important, that poor peoples’ voices should be central...so we made our list of things that are filters.”

Sebastian Amah, a taxi driver from Lagos, Nigeria, who has been in Philadelphia since 1993, described what he learned through these LJR trainings as being a combination of production skills and political analysis:

I learned how to edit radio material, do interviews... [and to] know what's being doctored. Now I understand that news can be altered. That it not necessarily didn't have to be the way they told it to you. It might have been a whole other way. By the time you get it, it's the way they want you to have it and for whatever reason the person whose documenting it you're gonna get it that way ... and it made me have doubts about the news. I used to be the type of person that accepted everything that I've seen on the TV...And I know that in the news world out there that you might have a great story but if the editor does not want to release it that won't be the story.

The teaching sessions also included technical trainings on the equipment as well as interviewing and editing skills. McKay prepared a radio manual, "Making our own Radio,” to be a reference for people who were in the trainings. It includes a list of goals, such as "representing workers in a positive and realistic way," "connect with listeners and attract people to get involved," "build consciousness," "use radio as a tool for building solidarity with other workers," "show how labor issues are connected to other social issues," "use radio as organizing tool,” "mobilize people” 
and "build power." It also details how to prepare a radio segment, including "brainstorming a topic," getting background information, writing and recording a story, editing, using digital recorders, and "tips for sounding good on the air."

People who took part in the trainings ultimately became the producers of Labor Justice Radio and were then asked to help run the next round of radio trainings. One of the trainers in the second round was Ken Davis, a janitor and member of SEIU 32BJ. Davis said that teaching was a chance for him to pass down the skills he had learned and help build a stronger radio program. This approach to training illustrates MMP's quest to move away from speaking in the name of poor and working people to building platforms and practices for those communities to speak for themselves. To do so, as LJR demonstrates, requires equipping people with the skills and tools to amplify their voices.

The Labor Justice Radio thus speaks to several dimensions within a localized media strategy for converging networks — such as MMP—in the neoliberal city. Taxi drivers are exemplary in many ways for the service sector of atomized, individual contractors without the right to unionize. The fact that cab drivers have constant access to the radio made this medium an important organizing tool to first generate connections between the individual and isolated taxi drivers. Beyond generating community between taxi drivers, however, Labor Justice Radio also provides a space for poor and working class people from the different network groups to work together, to build deeper relationships amongst them, and thus to foster an ever tighter network. LJR thus seeks to congeal the individual groups of the MMP network out from first generating tighter knit networks between the cab drivers to linkages between them and other 
groups of the MMP network to ultimately aspire to produce a movement for the city comprised of a shared identity and understanding of the diversity of groups in the MMP network.

Building the critical analytic skills of people in MMP and its affiliated groups is essential to this process. As McKay put it in an interview, the trainings are designed to help people produce stories that either support a group’s organizing or helps the listener "make some connection that they didn't have before.” The connections are not only generated through the final product and thus online, or in this case on air. Labor Justice Radio illustrates the grounding of network strategies adding a further dimension to the notion that networks are constituted by media flows.

The continuous process of putting the shows together as McKay points out, helps foster "a shared class identity" among the groups involved. Much more than a local radio program, McKay argues that media and communication are tools for "carving out more and more space" for poor and working people. Reflecting on the class afterward, McKay notes that most of the participants came in "very focused on their own union and kind of putting forward the things that they were working on specifically.” She saw one key role of the training to help participants see the similarities across their different groups and campaigns.

[W] hat we tried to do was to create a show that was focused on issues that really affected workers but also just working people across the city and poor people across the city. So some of the original curriculum was people going and doing interviews or stories about another group besides their own so that people would start [to] see those connections and than having conversations about the ways that even though there were differences in the way the mainstream media covered drivers versus, like, janitors that that no one was 
really getting their story told and no one was getting, like, a fair shake by the media at all. So people started to kind of build an idea for a show that was more than just these collective unions. There is definitely still a strong focus on labor but we also try to talk about the budget cuts, the casino that is proposed to come in, housing, sometimes education, sometimes we pull from the student unions radio show and share content. So, I think we are working towards something that is bigger.

This view is shared by many involved with producing the LJR program. For example, Al Robinson, a 28-year veteran shop steward and union organizer for SEIU 32BJ, pointed out that the radio show

allows us to blend and coexist a network with other people even though they have different issues like there are people in the clothing industry, people in the commercial industries, people in the residential industries, and now I find myself more involved with these people all the time because now we are networking and share information and finding out that we fight the same people all the time, just at different times. So our strategies become more stronger in dealing with these people and plus when they see us coming as an umbrella they give us a little more respect or listen to us a little better. Sitting next to him, Nawala Uusiku chimed in: “it’s like a fist—your hand is straight and if you close it and make a fist, it's all the groups together.” Nawala Usuiku's metaphor is illuminating for networking and movement building in an urban setting. The individual fingers stretched out symbolize the individual groups, the nodes of a network that inhabit the urban neoliberal landscape and move and struggle separately. They are, however, connected through both their conditions and resistance and when working in coordination, they are able to scale-up from the 
autonomous to a collective formation. This coordination is represented in Usuiku's metaphor, by the power of a fist, which in this case, Labor Justice Radio generated. Usuiku's comment also marks the centralized aspects of movement building within networks that arise when groups work together. The proliferation of organizations is part of the body politic of neoliberalism. But no less than fingers, organizations require coordination to come together as a fist. The scaling up, as well as the scaling across, of Labor Justice Radio demands of organizations and actors more strategic cooperation, leadership and thus arguably less autonomy, a reality that challenges the default setting that communicative movement-based networks are open and horizontal (Escobar, 2009 de Landa 2006).

The Labor Justice Radio example thus illustrates and complexifies our understanding of networked organizations. It is indicative of the context specific enactment of networks and its particular relation to the neoliberal city. Moreover, LJR also indicates the variability of network and media strategies in their relation to the particular groups and movements involved. Finally, it also shows and thus adds to our understanding of the relationship between network strategies and new media, emphasizing the necessity to understand contemporary urban networks as utilizing hybrid forms of online and offline spaces.

\section{Our City Our Voices}

A second example of how MMP employs media as a connective tissue for twenty-first century political mobilizing are its video trainings: Our City Our Voices (OCOV), a project of MMP and Juntos, a local community organization dedicated to the rights of Spanish-speaking immigrants in South Philadelphia. OCOV shows the fruitfulness of studying networks in local 
setting, as it forces us to descend from overly abstract contentions and to embed networks in their particular urban environment. Furthermore, it highlights the community building aspect of media in its on- and offline enactment in the actual daily practice of networks such as MMP and its constitutive groups and movements. As such, OCOV also illuminates how MMP grew beyond one of its forerunner, Indymedia, as it speaks to the limitations of Indymedia's often unfocused open source practice (Wolfson, 2009) by equipping the "new journalists" with the tools to produce quality journalism for a range of media. Moreover, MMP’s strategy also addresses one of public journalism's fatal flaws - limiting the conversation to those already within the professional community of journalists (Schudson, 1999). Rather than exhorting journalists to be more democratic or community minded, as the public journalism movement did (e.g., Carey, 1999; Charity, 1995; Merritt, 1995; Rosen, 1994; Rosen, 1999), MMP tries to get those on the other side of the digital divide the skills and hardware to be authors in the digital age.

The idea for the OCOV project grew during the mass protests for immigrant rights in 2006. Based on the mass outpouring, and a lack of immigrant voices in the mainstream media, members of MMP and Juntos wanted to use Philadelphia's plan for developing a municipal wireless internet network as a central backbone to getting immigrants and low-wage workers online and creating videos to share their stories and challenge the dominant discourse about immigrants that was growing in Philadelphia and across the United States. The two groups also wanted to bring Spanish-speaking immigrants into contact with students and other immigrant communities and low-wage workers throughout the city.

Supported by a grant from the Knight Foundation $21^{\text {st }}$ Century News Challenge, OCOV was comprised of video and web skill workshops that graduates learn after an eight-weekend- 
long training session. In addition, students also received wireless internet for a year as MMP was a Wireless Internet Partner (WIP) with Wireless Philadelphia (the city’s wireless internet network at the time). The workshop was structured in two parts. During the first section, students were trained in video and web skills and in the second section they go out and make videos about issues facing groups in the broader MMP network. The workshops and its products exemplify the strategic use of media for network building. The students were selected from groups and communities that MMP had targeted as important elements of a bigger movement. In the case of OCOV this strategy worked, as the videos students produced have been instrumental in forging tighter connections among groups within the MMP network, revealing the similarities between their struggles and prompting the further generating of cooperation and convergence. As Nawala Uusiku, who participated in both the OCOV trainings and in LJR, pointed out to us: "we kind of developed this sense of community. We are from different organizations but we became this community.”

The strategic role of communications is exemplified by a video interview MMP trainer Marissa Sanchez did with Natalia Vargas, a Mexican immigrant and student in the OCOV trainings. Natalia is a community organizer, working on women's health issues in the Mexican community. She cofounded the group "Health Promoters," which does community health education, and she helped organize a weekly health clinic in South Philadelphia. The interview focused on health care issues facing South-Philadelphia's Mexican community. While the clip ultimately became part of a couple different video news pieces, the interview was utilized by MMP organizers to illustrate health care concerns across low-income communities. 
For instance, the video was used by a group within the MMP network that focused on health issues and the rising cost of health clinics in Philadelphia. This group of Mexican immigrants, students and low-wage workers came together to think about MMP's organizing strategy around health care for poor and working class Philadelphians, particularly in light of the economic downturn. A core part of the initial meeting was a screening of the interview with Natalia, whom was not present. In the video, Natalia elaborated in Spanish on the health care situation of the Mexican community and during the screening, Marissa translated the video into English. This meeting tried to connect the health care deficits of the Spanish speaking, predominately Mexican immigrant community in Philadelphia to health care problems faced by students and taxi workers. Through the video and the face-to-face meeting, a closer alliance and consciousness among the poor and working class members of MMP was created based on shared experience around health care.

Ultimately the initial meeting led to the establishment of a committee made up by members of various groups within MMP that focused on the issue of healthcare for poor and working class communities. The committee focused on the immanent closure of Northeastern Hospital, a community hospital in North Philadelphia owned by Temple University. The closure of the hospital posed a danger to many poor and working class communities across the city, because of its location in a working class section of Philadelphia and correspondingly because it principally served Medicaid patients. The committee helped produce radio, video and blog segments on the impact of Northeastern's closure. The group also helped organize a rally around the closure of the hospital with a local nurses union PASNAP. A few months later, members of this group finished an hour-long special "Infection in our Health Care System,” focused both on 
the lack of quality health care in low-income communities and the plight of low-wage workers in the health care system.

The video workshops in general and the health care video in particular demonstrates the scaling up of linkages and ultimately convergences that we have already seen in the case of the Labor Justice Radio. Specific local circumstances_-Philadelphia’s plan for developing a municipal wireless internet network, the closure of a hospital—called forth a particular media networking strategy. Through MMP's media-making, individuals and groups that began focused on particular issues or conditions started to build relationships and develop coordination among other individuals and groups facing similar issues.

The first 20 learners graduated at the end of December of 2007, from MMP's Spanishlanguage workshop and those students are now making their own videos. These graduates produced six short documentaries on issues ranging from access to higher education, to workers and immigrants rights and community health. These videos were distributed on the OCOV website (http://ourcityourvoices.org/) as well as through public screening and through venues such as YouTube and local public TV station Drexel University TV (DUTV).

The aim of OCOV was originally to provide Spanish-speaking immigrants the tools to make news and video pieces about issues they face in their communities. Quickly, however, other MMP groups wanted to be able to learn these skills, too. Other groups in the MMP network wanted to receive media training, and the group decided it could not refuse their request. "[We couldn’t say] just because you are not an immigrant you are not going to get it," said Dara Curran, a filmmaker who helped coordinate the class. Hence, MMP coordinated an Englishspeaking training session. The first English-language workshop took place in February of 2008 
and was comprised of about 20 immigrants and other low-wage workers from the Taxi Workers Alliance, SEIU, Unite Here, African American Business and Residents Association, and PA Headstart, as well as the Cambodian Association of Greater Philadelphia and the Haitian Community Help Center—all groups which are linked to the MMP network. The MMP point people for OCOV were Perchik and Dara. Dara, a native from the greater Philadelphia area, has a background in media studies and is involved with public access television.

Originally from San Francisco, Perchik moved to Philadelphia about five years ago. She has a degree in film from the University of California at Santa Cruz and taught video classes for several years in Austin, Texas. During the day, learners were taught media skills but they also discussed the problems with mainstream media. While this format is similar to the one used by trainers in the LJR class, here the discussion focused more on digital media. Although there is some overlap between LJR and OCOV, the trainers, training curriculum and participants are all different. As part of this process people also addressed the need for net neutrality and municipal wireless systems to close the digital divide and learners also made videos detailing gentrification and problems in the Brewerytown neighborhood where the class was held. A class on video production became a space for connecting media reform issues to peoples' lives as well as to central challenges of the neoliberal city with respect to its impoverished neighborhoods and the politics of gentrification.

OCOV workshops followed a strategy of using media for movement building that takes seriously the off-line component of it, complicating the often simplistic understanding of new media in movement building. The online as well as offline components of OCOV are crucial for cross-group networking. As Perchik explained: 
[E]ven these classes and workshops were working within that framework of allowing people to have the space and access to tell their own stories but also to be able to then later plug in to MMP and cover events, their own events or other people in other networks, to build alliances with each other's struggles, which was amazing to actually see happening cause I have been working with MMP for a long time and have been hearing about connections of various networks and building this giant movement and it's really hard to sometimes see that and that big vision. But it was amazing because even when we were working with PSU [Philadelphia Student Union] specifically we were going covering the taxi cab workers' events and UNITE HERE and other union events, watching how everyone was actually showing up to each others work and really participating. ... I felt like it even heightened the importance of these skills and see that people can provide that for one another in their various struggles and also in their own.

The success of OCOV led organizers to design a strategy for more continuous cross-group fertilization and self-empowerment. As such, in the fall of 2008, OCOV initiated "master classes” for those that went through the initial training cycle. As Dara explains:

The idea is to sort of form a group of people that then can be active, out filming events and documenting meetings or issues that are coming up in a timely way and sort of turning them around on the blog in a fashion that is a fast production model. ... [The goal is to] train people that then can become autonomous kind of working units. So the master class would be like the meeting point for all of those people in a regular way but in between that there would be sense that these are the activities that are going on this week or this month and who is available to cover this. 
MMP’s Labor Justice Radio and OCOV video trainings illustrate the strategic use of media and communication by urban network formations in forging connections across otherwise isolated groups and movements in an attempt to create a shared identity and to build a broader movement of poor and working class constituencies. While this is the underlying aim of MMP, the work and strategy is not always successful. The lens of LJR, OCOV, or MMP's work on housing also indicates challenges and difficulties in organizing poor and working class constituencies particularly through media-based strategies. MMP faces the challenges of most grassroots groups — it is underfunded and overworked — while also struggling to balance its vision of utilizing media and communications to build a movement to end poverty with the daily needs of its network groups. In particular, MMP struggles to generate permanence within the increasingly transient nature of the work environment for the "precariat” (Wacquant, 2007). A video-training coordinator captures this difficulty stating that, "so much of this work is about relationship building and building trust and having longevity in the relationship[s] [but] the trainings are so short that I barely got to know the learners.”

This brings up a core question about the network model of organizing that MMP utilizes. Leaders within MMP made the strategic decision to organize already established anti-poverty organizations into one shared project, instead of building a specific base for the organization. The tension in this organizing model is that in circumstances such as the housing sector in Philadelphia where organizations do not survive, the decision to network organizations, instead of building a base, has repercussions on the organizations effectiveness. Put differently, local network strategies such as MMP’s where the focus is on forging linkages among already existing 
groups and movements heavily rely on the autonomous strength of its constitutive parts. While this strategy is also geared towards strengthening individual groups —or nodes — within the broader network of MMP, the emphasis is on the links between the nodes rather than on building a novel and specific base as is the case with more traditional organizational models such as labor unions or community/neighborhood based organizations.

\section{FRUIT}

MMP offers an example of collaborative networks rooted in a political affinity and media practice. Those concerned with media and social networks rightly point to the internet and assorted new media technologies that help facilitate transnational bonds (Cf., Arquilla \& Ronfeldt, 2001; Castells, 2000 [1996]; Cleaver, 1998). It is this connection that sparked the scholarly and popular fascination with Indymedia and other internet-based forms of political mobilization (Cf., Atton, 2004; Bennet, 2003). Our local focus suggests, however, that the emphasis on the internet as form of political mobilizations has to be problematized to fully understand new and old media’s role for urban based networks such as MMP. Furthermore, new media has a class bias. Given the intensive stratification that has accompanied neoliberalism, millions of people lack the means to participate in a technology-driven information economy. For many poor and working people, the network as an emergent political form is better served through a mixture of old and new media rather than an exclusive reliance on the latest media technology.

Our ethnographic data suggest that while the MMP network relies also on the internet, video and radio comprise vital aspects of media production by or oriented toward poor and 
working class people, who are often on the other side of the digital divide. In a city where 55 percent of the population lacks affordable and accessible broadband internet access (Dailey et al., 2010) new media cannot form the basis of broad-based networked mobilization that aims to work with poor and working-class constituencies. The ubiquity and variety of media in society, combined with the economic and political precarity faced by many contemporary urban residents, means that networks take shape across a range of media channels, including face-toface communication. The group's emphasis on radio programs, video documentaries, and DVD public service announcements, in addition to blog posts and Indymedia coverage, suggests that the forum for media networks are not limited to internet-based new media. Moreover, it suggests that the shape and structure of networks depend on the social position of the populations involved. Together, these realities point to the need for more integrated analyses of new media and social networks that account for the merging of media in response to the communities they serve. In short, the social, technological, and political sources of networks need to be read as interdependent phenomenon.

This use of communicative technology as an organizational response to neoliberal urbanism presents an alternate model of media production than the two that have dominated scholarly research: alternative media production such as Indymedia or policy-focused efforts at media reform (Berger, 2009). MMP straddles all three of the “umbrella categories” Opel (2004: 26) identifies in his typology of media activism: the group is a grassroots organization (involving independent media producers and creating distribution networks through its partner groups and public events) that is building institutions (focused on poor people's movements) and informed by academic discourse (about media, neoliberalism, social movements, and networks) which it 
contributes to through conference presentations and publications. MMP illustrates the material media practices that work to knot together communities with a common interest towards social change.

The group also raises the need for greater study into the role media and communications play in how collectives make sense of their class position and geographic location. Networks develop within and not just across cities; they are richly territorial, shaped by the specific political economies and cultural geographies in which they emerge. By examining networks in their local habitus, it becomes possible to examine their practice in greater depth. For it is in such local expressions that the work of networks manifest. As social movements challenge the fragmentation present within contemporary urban landscapes, they experiment with models of organization that bridge virtual and real modes of communication that can overcome the isolation wrought by poverty and marginalization. It is too early to tell whether such networks can combine democratic openness and strategic efficacy as they develop deeper roots as political institutions. Yet it seems clear that such networks are a growing force in the shape of urban politics. 
Bibliography

Aneesh, A. (2006). Virtual Migration: The Programming of Globalization. Durham: Duke University Press.

Arquilla, J. \& Ronfeldt, D., eds. (2001). Networks and Netwars: The Future of Terror, Crime, and Militancy. Santa Monica: RAND.

Atton, C. (2004). Alternative Internet. Edinburgh: Edinburgh University Press.

Beckerman, G. (2003). Edging Away from Anarchy: Inside the Indymedia Collective, Passion Vs. Pragmatism. Columbia Journalism Review, 42 (3), 27-30.

Bennett, W.L. (2003). New Media Power: The Internet and Global Activism. In N. Couldry \& J. Curran (Eds.), Contesting Media Power: Alternative Media in a Networked World (1737). Lanham, MD: Rowman \& Littlefield.

Berger, D. (2009). Special Section on Media Reform | Defining Democracy: Coalition Politics and the Struggle for Media Reform. International Journal of Communication [Online] 3.0. Available: http://ijoc.org/ojs/index.php/ijoc/article/view/285.

Brenner, N., \& Theodore, N., (2002). Spaces of Neoliberalism: Urban Restructuring in north America and Europe. Malden: Blackwell Publishers

Caldeira, T. (2001). City of Walls: Crime Segregation and Citizenship in Sao Paulo. Berkeley: University of California Press

Carey, J. (1999). In Defense of Public Journalism. In T.L. Glasser (Ed.), The Idea of Public Journalism (49-66). New York: Guilford.

Caruso, C. (2000, March 25). Coordinating On-line and Off-line Organizing. Paper delivered at Grassroots Use of the Internet conference, Yale Law School.

Castells, M. (2000 [1996]). The Rise of the Network Society. Oxford: Blackwell.

Charity, A. (1995). Doing Public Journalism. New York: Kettering Foundation.

Cleaver, H. (1998). The Zapatistas and the Electronic Fabric of Struggle. In J. Holloway \& E. Paláez (Eds.), Zapatista! Reinventing Revolution in Mexico (pp. 81-103), London: Pluto Press.

CIW. (2004). “Consciousness + Commitment = Change.” In D. Solnit (Ed.), Globalize Liberation: How to Uproot the System and Build a Better World (347-360). San 
Francisco: City Lights Books.

Day, R. (2005). Gramsci is Dead: Anarchist Currents in the Newest Social Movements. New York: Pluto Press

de Landa, M. (2006). A New Philosophy of Society: Assemblage Theory and Social Complexity. London, New York: Continuum

Della Porta, D., M. Andretta, L. Mosca, \& H. Reiter. (2006). Globalization from Below: Transnational Activists and Protest Networks. Minneapolis: University of Minneapolis Press.

Dailey, D., Bryne, A., Powell, A., Karganais, J., \& Chung, J. (2010) Broadband Adoption in Low- Income Communities. New York: Social Science Research Council

Dyer Witheford, N. (1999). Cyber Marx: Cycles and Circuits of Struggle in High-Technology Capitalism. Urbana: University of Illinois Press.

Escobar, A. (2008) Territories of Difference: Place, Movements, Life, Redes. Durham, Duke University Press.

Fox Piven, F. \& R. Cloward. (1979). Poor People's Movements: How They Succeed, Why They Fail. New York: Vintage Books.

Gillmor, D. (2004). We the Media: Grassroots Journalism by the People, for the People. Sebastopal, CA: O’Reilly.

Goode, J., Maskovsky, J. (2001). The New Poverty Studies: The Ethnography of Power, Politics and Impoverished People in the United States. New York: NYU Press

Hale, C. (2008). Engaging Contradictions: Theory, Politics, Methods of Activist Scholarship. Berkeley: University of California Press

Halleck, D. (2002). Hand Held Visions: The Impossible Possibilities of Community Media. New York, Fordham University Press

Hardt, M. \& Negri, A. (2004). Multitude: War and Democracy in the Age of Empire. New York: Penguin Press.

Harvey, D. (2005). A Brief History of Neoliberalism. Oxford: Oxford University Press.

Herman, E. \& Chomsky, N. (1988). Manufacturing Consent: The Political Economy of the Mass Media. New York: Pantheon Books. 
Holloway, J., Peleaz, E. (1998). Zapatista! Reinventing Revolution in Mexico. Sterling VA: Pluto Press

Jackson, T. (2007). From Civil Rights to Human Rights: Martin Luther King, Jr., and the Struggle for Economic Justice. Philadelphia: University of Pennsylvania Press.

Juris, J.S. (2005). The New Digital Media and Activist Networking within Anti-Corporate Globalization Movements. Annals of the American Academy of Political and Social Sciences 597: 189-208.

. (2008). Networking Futures: The Movements Against Corporate Globalization. Durham: Duke University Press.

Keck, M., Sikkink, K. (1998) Activists Beyond Borders: Advocacy Networks in International Politics. Ithaca: Cornell Univesity Press.

Khasnabish, A. (2008). Zapatismo Beyond Borders: New Imaginations of Political Possibility. Toronto: University of Toronto Press.

Kidd, D. (2003). Indymedia.org: a new communications commons. In M. McCaughey \& M.D. Ayers (Eds.), Cyberactivism: Online Activism in Theory and Practice (47-70). New York: Routledge.

Massey, D., \& Denton, N. (1998). American Apartheid: Segregation and the Making of the American Underclass. Cambridge: Harvard University Press

McCaughey, M., \& Ayers, M. (2003) Cyberactivisim: Online Activism in Theory and Practice. New York: Routledge.

Merritt, D. (1995). Public Journalism and Public Life: Why Telling the News is Not Enough. Hillsdale, NJ: Lawrence Erlbaum.

Morris, D. (2003). Globalization and Media Democracy: The Case of Indymedia. In D. Schulyer \& P. Day (Eds.), Shaping the Network Society, (pp. 325-352). Boston: MIT Press.

Nogueira, A. (2002). The Birth and Promise of the Indymedia Revolution. In B. Shepard \& R. Hayduk (Eds.), From ACT UP to the WTO: Urban Protest and Community Building in the Era of Globalization (pp. 274-289). London: Verso.

Nugent, D. (1995). Northern Intellectuals and the EZLN. The Monthly Review v. 47 n. 3, pp. 124-138 
Opel, A. (2004). Micro Radio and the FCC: Media Activism and the Struggle Over Broadcast Policy. Westport, CT: Praeger.

Opel, A. \& R. Templin (2005). Is anybody reading this? Indymedia and internet traffic reports. Transformations 10: http://transformations.cqu.edu.au/journal/issue_10/article_08.shtml.

Platon, S. \& Deuze, M. (2003). Indymedia Journalism: A Radical Way of Making, Selecting, and Sharing News? Journalism 4 (3), 336-355.

Rondfelt, D., Arquilla, J. (1998). The Zapatista Social Netwar in Mexico. Santa Monica, CA: Rand Corporation.

Rosen, J. (1994). Making Things More Public: On the Political Responsibility of the Media Intellectual. Critical Studies in Mass Communication, 11 (4), 362-388.

. (1999). The Action of the Idea: Public Journalism in Built Form. In T.L. Glasser (Ed.), The Idea of Public Journalism (21-48). New York: Guilford.

Sanday, P. (1976). Anthropology and the Public Interest: Fieldwork and Theory. New York: Academic Press

. (1990) Fraternity Gang Rape: Sex, Brotherhood and Privilege on Campus. New York: New York University Press

Schudson, M. (1999). What Public Journalism Knows about Journalism but Doesn't Know about “Public.” T.L. Glasser (Ed.), The Idea of Public Journalism (118-133). New York: Guilford.

Sellers, J. (2004). Raising a Ruckus. In T. Mertes (Ed.), A Movement of Movements: Is Another World Really Possible? (175-191). New York: Verso.

Setchell, L. (2002). Democratizing Media. In M. Prokosch \& L. Raymond (Eds.), The Global Activist's Manual: Local Ways to Change the World (pp. 187-188). New York: Thunder's Mouth Press/ Nation Books.

Sites, W. (2009). Beyond Trenches and Grassroots: Reflections on Urban Mobilization, Fragmentation and the Anti-Wal-Mart Campaign in Chicago," Environment and Planning A. 39(11) 2632-2651

Smith, N. (1996). The New Urban Frontier: Gentrification and the Revanchist City. New York: ‘ Routledge.

Wacquant, L. (2007). Territorial Stigmatization in the Age of Advanced Marginality. Thesis Eleven 91: 66-77. 
Wolfson, T. (2009). The Cyber Left: Indymedia and The Making of Twenty-First Century Struggle. Ph.D. Dissertation, University of Pennsylvania. 